\title{
An illustration of lactation curves stratified by lactation yields within herd
}

Dedicated to Professor Dr. Peter Glodek on the occasion of his $65^{\text {th }}$ birthday

\begin{abstract}
Summary
Based on the lactation curves of a total of 817 cows from three herds the variation of the shape of lactation curves is illustrated stratified by herd, lactation number and total lactation production. The data was collected from on-farm computers connected to recording of yields on a daily basis. The results from this ongoing project show that a differentiation of cows according to total yield per lactation or 305-day yield based on records from early lactations is difficult and thus highly questions the set-up of yield groups in the beginning of the lactation. The results also illustrate that it is still debatable what kind of criterion for the persistency of lactation production should be used. This question should be answered in relation to the desired length of lactation. Today, random regression models for the genetic evaluation of dairy animals seem to be a promising alternative to more traditional methods. Future research in this field should make use of data from daily recordings since by this the impact of the data structure can be analysed by mimicking different recording scenarios.
\end{abstract}

Key Words: Lactation curves, daily milk recording, persistency, random regression models

\section{Zusammenfassung}

Titel der Arbeit: Eine Illustration von Laktationskurven stratifiziert nach Laktationsleistung innerhalb Herde

Auf der Basis der Laktationskurven von 817 Kühen aus drei Herden wird eine Illustration der Form der Laktationskurven, stratifiziert nach Herde, Laktationsnummer und Gesamtleistung der Laktation gegeben. Das Datenmaterial wurde von Hofcomputern übernommen, die mit Einrichtungen zur täglichen Erfassung der Milchmenge verbunden waren. Die Ergebnisse zeigen, daß eine Einteilung von Kühen in Leistungsklassen gemäß der Laktationsleistung, aber auch der 305-Tage-Leistung, basierend auf Leistungen am Anfang der Laktation sehr schwierig ist und stellt deshalb Gruppeneinteilungen am Beginn der Laktation in Frage. Die Ergebnisse illustrieren auch, daß es nach wie vor umstritten ist, welche Art von Kriterium für die Persistenz der Laktation zu benutzen ist. Diese Frage sollte in Relation zur gewünschten Laktationslänge beantwortet werden. Modelle mit zufälliger Regression zur Zuchtwertschätzung auf Milchleistung erscheinen heute als vielversprechende Alternativen zu den traditionellen Verfahren. Zukünftige Forschung in diesem Gebiet sollte Daten aus der täglichen Erfassung der Milchmenge nutzen, da hiermit der Einfluß der Datenstruktur durch die Simulation verschiedener Kontrollszenarien analysiert werden kann.

Schlüsselwörter: Laktationskurven, tägliche Milchmengenerfassung, Persistenz, Modelle mit zufälliger Regression

\section{Introduction}

Mathematical functions to describe the shape of the lactation curve have been discussed among animal scientists for a long time. WOOD (1967) presented a model 
that became widely known and used due to its simplicity and capability of describing the ascending and descending phase of a milk yield curve in relation to the stage of the lactation. Numerous work on lactation curves has been done since that time, for a review see MASSELIN et al. (1987) and later reviews by OLORI (1997) and GUO (1998). Functions describing the lactation curve have been used for the prediction of total and peak yields, for analyses of the impact of environmental factors (e.g. WOOD, 1976) and recently also for modelling of genetic effects. The recent interest reaching as far as modelling of genetic effects arose from the suggestion to use test day records instead of lactation records for the genetic evaluation of animals. A test day is the day on which the milk production of a dairy animal is recorded. Intervals between test days commonly follow sampling schemes run by dairy recording agencies. Up to now, in most countries test day records have been aggregated by simple procedures to form lactation records. Test day models offer the feature that the individual records can be processed directly thus enabling corrections for environmental effects at the test day level. By this, effects that change over time can be modelled directly. For reviews on test day models see SWALVE $(1995,1998,1999)$.

Test day models that consider test day records as repeated observations within a lactation can be denoted as One-Step models as opposed to Two-Step models which comprise corrections on a test day level but then process lactation records after aggregation of the corrected records. One-Step models nowadays are usually repeatability animal models that include environmental effects, a genetic animal effect and an effect of the permanent environment of the lactation. Furthermore, in these models it is crucial to account for the stage of the lactation. This correction commonly is done by the use of appropriate coefficients of regression and may be denoted as a sub-model within the animal model. Lactation curve functions are ideal candidates for these sub-models and this explains the recent increase of interest in functions describing the lactation curve.

SCHAEFFER and DEKKERS (1994) introduced the concept of additionally modelling the animal's genetic effect as a set of regression coefficients with a covariance structure among them. The general concept of random regressions has been suggested by HENDERSON Jr. (1982) and HENDERSON (1984). As has been shown meanwhile, also the remaining random effects, i.e. permanent environment and the residual have to be modelled using random regressions, or, in the case of the residual at least different measurement errors have to be defined (JAMROZIK et al., 1997). Hence, in a random regression model sub-models are used for fixed corrections of the lactation stage nested within appropriate sub-groups such as region, season of calving or classes of calving interval and furthermore for random effects. This enforces the need to find appropriate sub-models although recent research also provides alternatives in the use of completely arbitrary functions in the form of so-called covariance functions (MEYER and HILL, 1997).

Random regression models are computationally very demanding and therefore they are, at least at present, difficult to implement for national routine evaluations on a large scale in countries with a large population under milk recording such as the USA or 
Germany. The question arises, what is gained by random regression models. Or, in other words, whether and how much of the genetic variation in the course of the lactation can be explained by a non-constant term. Up to now, two studies have concluded that about 7 to $11 \%$ of the genetic variation in the course of the lactation is non-constant (OLORI, 1997; VAN DER WERF et al., 1998). Given the computational demand, this finding would probably favour the use of fixed sub-models only. Furthermore, the estimation of the covariance matrices necessary for a random regression model is difficult and has seen some curious results (MISZTAL, 1999). Further research in this field is necessary.

Results from studies on random regression models and the estimation of covariances to be used in them are highly dependent on the data structure. Missing test day information in parts of the lactation has a great influence (POOL and MEUWISSEN, 1999). An ideal data set for the analysis of the use of random regression models should have daily observations so that different scenarios can be considered. In an ongoing project GUO (1998) and GUO and SWALVE $(1995,1997)$ have used data collected on-farm consisting of daily recordings of milk yield for a comparison of lactation curve functions on a phenotypic level. Aim of the present study was to use the data of GUO (1998) for a comparison of lactation curves stratified by herds, lactations and level of production as an illustration of the general problem to model lactation curves.

\section{Material and Methods}

Only parts of the data used by GUO (1998) were used in this study. The data comprised daily milk yield records from three herds: Herd A, a very large herd with an average production level, herd B, a large farm with a high level of production, and herd C, an experimental farm with high yields. Test day records for herd A were collected between January, 1996 and March, 1997, for herd B between January 1996 and November, 1997, and for the experimental farm data had been supplied from the period of November, 1988 to May, 1994. Hence, especially for herds A and B the data collected do not reflect actual herd sizes since only complete lactations were considered and therefore only lactations were included that were initiated and completed within the period specified.

Completeness of the data was different between the two practical farms and the experimental farm. On the two large-scale practical farms missing values for individual days were common due to technical misidentification, cows being taken to separate barns because of diseases and other causes. On the much smaller experimental farm, all cows always were milked in the parlour equipped with the recording device. For all three farms, common edits were the requirement of the first recorded milking day not later than 9 days (10 days for herds A and B) after calving, a lactation length between 250 and 450 days and a total lactation milk yield of greater $3000 \mathrm{~kg}$. For herds A and B furthermore the maximum number of missing values throughout the lactation was set to 21 and the maximum number of missing observations on subsequent days was 8 .

For the present study only cows with a lactation yield of greater $5000 \mathrm{~kg}$ were included. Classes of production level were defined for total lactation yields of 5000 to 
$5999 \mathrm{~kg}$ (1), 6000 to $6999 \mathrm{~kg}$ (2), 7000 to 7999 (3) and 8000 and higher (4).

The methods used for this study were purely descriptive. For a mathematical modelling of lactation curves the MIL (mixed log) function developed by GUO and SWALVE (1995) was used. The MIL function is a three parameter function with a reasonable fit (GUO and SWALVE, 1995, 1997) and defined as:

$$
\mathrm{yt}=\mathrm{a}+\mathrm{b} \sqrt{\mathrm{t}}+\mathrm{c} \ln (\mathrm{t})
$$

Where $t$ denotes time (days in milk $=$ DIM) and $a, b, c$ are parameters to be estimated. Estimation was done based on scenario in which the first test day is on DIM=20 and samples are subsequently taken in regular intervals of 30 days.

\section{Results}

In Table 1 the raw means of test day records for the scenario chosen are given by herds, lactation number and class of total lactation milk yield along with the number of cows for each class. It should be noted, that for the two last test days not all cows had records. An unexpected finding is the fact that on the first test day used (DIM=20) cows in the highest yield class which was even left as an 'open' class quite frequently show lower yields than cows from lower yield classes. This is especially evident for herd $\mathrm{A}$ in the first lactation. In all herds and third lactations, the starting yield for the highest yield class is more or less equal to that one of the second highest yield class. In all herds and lactations, however, the averages of individual test days from the second trimester of lactation onwards are in accordance to the grouping of total lactation yield class.

At least part of this finding may be explained by the difference in lactation lengths. In Table 2 averages for lactation length are given along with the estimated parameters from the MIL function and along with the averages of actual total yields and estimated total yields. For sake of comparison, Table 2 also includes 305-day yields (last column) calculated using the given parameters of the MIL function. From this column it can be seen that with the exception of first lactations in herd A, the differentiation according to classes of total yield is equally maintained when inspecting 305-day yields. The exceptional case of the highest yield class in first lactations in herd A is an example for cows starting at an intermediate level of production but then maintain rather long lactations.

The results are represented graphically in Figures 1 to 4 for herds A and B. For the lactation curves displayed smoothed curves were plotted using the parameters estimated from the MIL function. When comparing Figures 1 and 2 (first lactations) with respect to the curves for the two highest yield classes, quite contrary observations are made for herds A and B. In herd A cows with highest yields start at a low level but then continue to produce at a high level exhibiting an almost flat lactation curve leading to a long length of lactation. In herd B highest producers show quite peaked lactation curves. The lactation length of the two highest yield classes here is nearly equal (see Table 2, 349 vs. 345 days). 
Arch. Tierz. 42 (1999) 6

Table 1

No. of cows and average test day record for test days on DIM $=20$ to DIM $=290$ (in 30 day intervals) by herd, lactation no. and yield class (Anzahl Kühe und mittlere Kontrolltagsleistung für die Kontrolltage von Tag 20 bis Tag 290 (in 30-Tage-Intervallen) nach Herde, Laktationsnummer und Leistungsklasse)

\begin{tabular}{|c|c|c|c|c|c|c|c|c|c|c|c|}
\hline \multirow{2}{*}{$\begin{array}{l}\text { Yield } \\
\text { class }\end{array}$} & \multirow{2}{*}{$\begin{array}{c}\text { No. of } \\
\text { cows }\end{array}$} & \multicolumn{10}{|c|}{ Test day } \\
\hline & & 20 & 50 & 80 & 110 & 140 & 170 & 200 & 230 & 260 & 290 \\
\hline \multicolumn{12}{|c|}{ Herd $\mathrm{A}, 1$. lactations } \\
\hline 1 & 103 & 21.50 & 21.84 & 20.69 & 19.87 & 18.26 & 17.95 & 15.96 & 15.08 & 13.28 & 11.52 \\
\hline 2 & 47 & 23.21 & 23.68 & 23.66 & 21.63 & 19.77 & 20.33 & 19.24 & 18.59 & 16.47 & 14.06 \\
\hline 3 & 15 & 24.43 & 26.52 & 24.93 & 23.35 & 22.66 & 21.26 & 20.95 & 20.35 & 19.37 & 18.84 \\
\hline 4 & 7 & 21.03 & 26.63 & 21.94 & 23.66 & 23.37 & 19.67 & 20.37 & 20.37 & 21.16 & 21.71 \\
\hline \multicolumn{12}{|c|}{ Herd B, 1. lactations } \\
\hline 1 & 11 & 24.26 & 23.14 & 21.86 & 21.05 & 20.00 & 18.11 & 18.39 & 15.65 & 14.03 & 13.21 \\
\hline 2 & 29 & 24.28 & 24.24 & 23.49 & 22.60 & 22.13 & 20.44 & 19.90 & 19.39 & 17.94 & 15.28 \\
\hline 3 & 27 & 25.36 & 25.54 & 26.01 & 24.15 & 23.35 & 22.79 & 21.91 & 21.99 & 21.23 & 18.00 \\
\hline 4 & 13 & 27.12 & 29.85 & 28.88 & 27.15 & 25.58 & 25.62 & 23.73 & 21.49 & 22.39 & 20.67 \\
\hline \multicolumn{12}{|c|}{ Herd C, 1 . lactations } \\
\hline 1 & 30 & 20.79 & 22.18 & 21.30 & 19.60 & 18.29 & 16.52 & 15.73 & 14.49 & 13.70 & 12.80 \\
\hline 2 & 23 & 23.96 & 26.40 & 24.97 & 23.78 & 21.71 & 20.19 & 18.95 & 17.61 & 16.21 & 14.01 \\
\hline 3 & 9 & 26.66 & 29.31 & 28.02 & 26.62 & 25.01 & 23.14 & 22.79 & 21.56 & 19.16 & 16.96 \\
\hline 4 & 2 & 31.90 & 35.15 & 33.40 & 33.80 & 30.75 & 31.80 & 29.65 & 26.40 & 23.25 & 22.60 \\
\hline \multicolumn{12}{|c|}{ Herd A, 2. Lactations } \\
\hline 1 & 51 & 27.87 & 26.49 & 24.76 & 23.29 & 20.51 & 18.08 & 15.58 & 13.33 & 11.29 & 7.92 \\
\hline 2 & 30 & 29.83 & 28.56 & 26.15 & 25.02 & 23.12 & 21.61 & 19.17 & 17.09 & 13.99 & 12.29 \\
\hline 3 & 23 & 33.33 & 30.75 & 29.23 & 25.36 & 23.52 & 22.23 & 20.80 & 19.96 & 16.29 & 14.49 \\
\hline 4 & 5 & 27.66 & 31.70 & 33.02 & 29.60 & 26.90 & 26.32 & 25.76 & 22.30 & 20.26 & 20.16 \\
\hline \multicolumn{12}{|c|}{ Herd B, 2. Lactations } \\
\hline 1 & 1 & 23.70 & 22.30 & 20.50 & 7.20 & 13.70 & 15.20 & 13.60 & 13.90 & 12.90 & 11.00 \\
\hline 2 & 7 & 32.14 & 30.53 & 27.59 & 24.31 & 21.56 & 18.17 & 15.36 & 15.39 & 14.19 & 11.70 \\
\hline 3 & 9 & 33.61 & 32.13 & 27.23 & 26.91 & 24.39 & 20.57 & 20.78 & 16.99 & 17.72 & 14.44 \\
\hline 4 & 8 & 36.67 & 37.27 & 32.45 & 28.76 & 25.45 & 24.00 & 22.81 & 22.30 & 21.16 & 18.69 \\
\hline \multicolumn{12}{|c|}{ Herd C, 2. lactations } \\
\hline 1 & 13 & 24.96 & 25.28 & 22.95 & 20.41 & 18.20 & 17.62 & 15.45 & 13.96 & 12.82 & 10.93 \\
\hline 2 & 20 & 29.50 & 28.99 & 28.07 & 24.50 & 22.07 & 20.79 & 19.02 & 17.45 & 15.17 & 11.44 \\
\hline 3 & 16 & 32.66 & 34.76 & 31.64 & 28.90 & 25.45 & 23.73 & 21.78 & 19.29 & 17.07 & 13.98 \\
\hline 4 & 10 & 32.57 & 36.15 & 32.06 & 30.48 & 27.51 & 25.07 & 23.68 & 21.60 & 21.08 & 18.87 \\
\hline \multicolumn{12}{|c|}{ Herd $\mathrm{A}, 3$. and higher lactations } \\
\hline 1 & 57 & 27.08 & 27.71 & 24.68 & 22.85 & 20.34 & 17.42 & 15.17 & 12.69 & 10.67 & 8.42 \\
\hline 2 & 54 & 32.71 & 31.19 & 27.99 & 24.29 & 22.85 & 20.61 & 18.66 & 16.58 & 13.43 & 10.37 \\
\hline 3 & 29 & 33.39 & 34.32 & 29.38 & 27.21 & 25.41 & 20.86 & 20.70 & 19.93 & 17.13 & 13.80 \\
\hline 4 & 10 & 34.32 & 32.70 & 30.63 & 30.30 & 23.78 & 23.33 & 22.56 & 21.82 & 19.50 & 16.53 \\
\hline \multicolumn{12}{|c|}{ Herd B, 3. and higher lactations } \\
\hline 1 & 8 & 27.34 & 26.09 & 24.19 & 23.56 & 20.64 & 17.54 & 15.68 & 13.51 & 12.71 & 10.80 \\
\hline 2 & 16 & 29.96 & 31.97 & 28.53 & 25.46 & 23.67 & 20.34 & 15.86 & 15.09 & 13.39 & 11.26 \\
\hline 3 & 13 & 34.42 & 36.53 & 31.78 & 29.41 & 25.38 & 22.65 & 18.50 & 17.76 & 12.94 & 12.62 \\
\hline 4 & 11 & 33.72 & 33.69 & 30.72 & 29.04 & 25.90 & 22.80 & 22.74 & 19.62 & 18.25 & 17.24 \\
\hline \multicolumn{12}{|c|}{ Herd C, 3 . and higher lactations } \\
\hline 1 & 15 & 27.73 & 27.79 & 25.11 & 22.60 & 21.13 & 17.60 & 15.67 & 13.50 & 12.33 & 9.06 \\
\hline 2 & 27 & 29.99 & 30.54 & 27.79 & 24.77 & 22.97 & 19.65 & 17.06 & 15.73 & 13.95 & 11.66 \\
\hline 3 & 41 & 33.74 & 35.98 & 32.78 & 30.17 & 26.98 & 23.63 & 20.92 & 18.33 & 15.37 & 12.82 \\
\hline 4 & 27 & 34.20 & 36.16 & 33.91 & 31.44 & 28.83 & 27.10 & 23.43 & 20.56 & 17.69 & 15.08 \\
\hline
\end{tabular}

When comparing third and higher lactations (Figures 3 and 4) for all three herds (herd $\mathrm{C}$ not shown) at the beginning of the lactation cows with highest lactation yields can 
not be differentiated from the second highest class. In all three herds the highest class exhibits a better persistency of lactation production leading to longer lengths of lactation. However, the classes of total yield production do not solely reflect differences in lactation lengths as they also differ in 305-day production.

Table 2

Estimated parameters of MIL-Function $(a, b, c)$ along with averages of actual lactation yield and average of estimated lactation yield and 305-day yield estimated from resulting parameters by herd, lactation number and class of lactation yield level (Geschätzte Parameter der MIL-Funktion (a,b,c), mittlere tatsächliche Laktationsleistung und mittlere geschätzte Laktationsleistung sowie aus den Parametern geschätzte 305-Tage Leistung nach Herde, Laktationsnummer und Leistungsklasse)

\begin{tabular}{|c|c|c|c|c|c|c|c|c|c|}
\hline Herd & $\begin{array}{l}\text { Lact. } \\
\text { no. }\end{array}$ & Class & $\begin{array}{l}\text { Length } \\
\text { of lact. }\end{array}$ & a & b & c & $\begin{array}{l}\text { Ave. act. } \\
\text { yield }\end{array}$ & $\begin{array}{c}\text { Ave. est. } \\
\text { yield }\end{array}$ & $\begin{array}{c}\text { Est. } 305-d \\
\text { yield }\end{array}$ \\
\hline A & 1 & 1 & 322 & 10.4344 & -2.22026 & 6.9592 & 5441 & 5475 & 5325 \\
\hline A & 1 & 2 & 347 & 12.4335 & -2.03757 & 6.6070 & 6446 & 6621 & 6076 \\
\hline A & 1 & 3 & 355 & 17.4522 & -1.54113 & 4.7979 & 7226 & 7565 & 6763 \\
\hline A & 1 & 4 & 406 & 14.0763 & -1.11085 & 4.3837 & 8337 & 8529 & 6667 \\
\hline A & 2 & 1 & 292 & 13.6586 & -3.63626 & 10.0496 & 5448 & 5582 & 5729 \\
\hline A & 2 & 2 & 318 & 18.5837 & -3.07581 & 8.2208 & 6472 & 6683 & 6586 \\
\hline A & 2 & 3 & 337 & 31.8088 & -2.26591 & 3.8711 & 7393 & 7575 & 7224 \\
\hline A & 2 & 4 & 317 & 0.5345 & -3.89945 & 14.9823 & 8273 & 8096 & 7909 \\
\hline A & 3 & 1 & 297 & 12.0720 & -3.79235 & 10.7209 & 5527 & 5565 & 5658 \\
\hline A & 3 & 2 & 312 & 26.0058 & -3.19263 & 7.0019 & 6437 & 6680 & 6674 \\
\hline A & 3 & 3 & 327 & 26.7407 & -3.03516 & 6.9493 & 7447 & 7586 & 7383 \\
\hline A & 3 & 4 & 371 & 30.4245 & -2.42855 & 4.9660 & 8434 & 8685 & 7803 \\
\hline B & 1 & 1 & 308 & 17.8735 & -1.86954 & 4.8329 & 5694 & 5764 & 5773 \\
\hline B & 1 & 2 & 325 & 15.2425 & -1.80427 & 5.6360 & 6502 & 6628 & 6362 \\
\hline B & 1 & 3 & 345 & 16.8039 & -1.56951 & 5.1625 & 7511 & 7680 & 6990 \\
\hline B & 1 & 4 & 349 & 13.4621 & -2.31012 & 8.1434 & 8470 & 8421 & 7638 \\
\hline B & 2 & 1 & 386 & 46.2512 & 0.71477 & -8.1832 & 5772 & 5674 & 4839 \\
\hline B & 2 & 2 & 321 & 31.9357 & -2.57919 & 4.0954 & 6507 & 6544 & 6471 \\
\hline B & 2 & 3 & 335 & 33.7671 & -2.23815 & 3.3703 & 7482 & 7503 & 7197 \\
\hline B & 2 & 4 & 330 & 40.6863 & -1.96602 & 1.9838 & 8491 & 8600 & 8275 \\
\hline B & 3 & 1 & 294 & 17.9796 & -2.92575 & 7.4613 & 5505 & 5681 & 5840 \\
\hline B & 3 & 2 & 300 & 13.6696 & -4.11513 & 11.7766 & 6420 & 6438 & 6520 \\
\hline B & 3 & 3 & 319 & 17.2023 & -4.65280 & 12.9163 & 7405 & 7413 & 7329 \\
\hline B & 3 & 4 & 363 & 26.7580 & -2.82689 & 6.6740 & 8439 & 8470 & 7732 \\
\hline C & 1 & 1 & 328 & 10.6857 & -2.10959 & 6.6228 & 5529 & 5536 & 5310 \\
\hline C & 1 & 2 & 334 & 7.0474 & -2.95125 & 10.1275 & 6487 & 6601 & 6263 \\
\hline $\mathrm{C}$ & 1 & 3 & 329 & 8.4826 & -2.99756 & 10.5973 & 7418 & 7575 & 7214 \\
\hline C & 1 & 4 & 289 & 5.6903 & -3.75551 & 14.2835 & 8502 & 8587 & 8985 \\
\hline C & 2 & 1 & 311 & 18.6504 & -2.37580 & 5.7698 & 5482 & 5572 & 5560 \\
\hline $\mathrm{C}$ & 2 & 2 & 306 & 17.4014 & -3.22810 & 8.8456 & 6537 & 6550 & 6585 \\
\hline $\mathrm{C}$ & 2 & 3 & 322 & 15.2951 & -4.06287 & 12.0117 & 7617 & 7703 & 7541 \\
\hline C & 2 & 4 & 343 & 18.6543 & -3.32573 & 9.9092 & 8515 & 8707 & 8155 \\
\hline C & 3 & 1 & 295 & 15.6823 & -3.42512 & 9.1791 & 5649 & 5713 & 5841 \\
\hline C & 3 & 2 & 314 & 18.4424 & -3.46444 & 9.1508 & 6478 & 6536 & 6502 \\
\hline C & 3 & 3 & 318 & 10.8498 & -4.94011 & 15.1282 & 7567 & 7664 & 7562 \\
\hline C & 3 & 4 & 333 & 8.7866 & -4.86408 & 15.7385 & 8396 & 8411 & 8084 \\
\hline
\end{tabular}

Discussion

The results here were obtained from a small data set on a purely phenotypic level uncorrected for any environmental effects. Therefore they were only given in a form of 


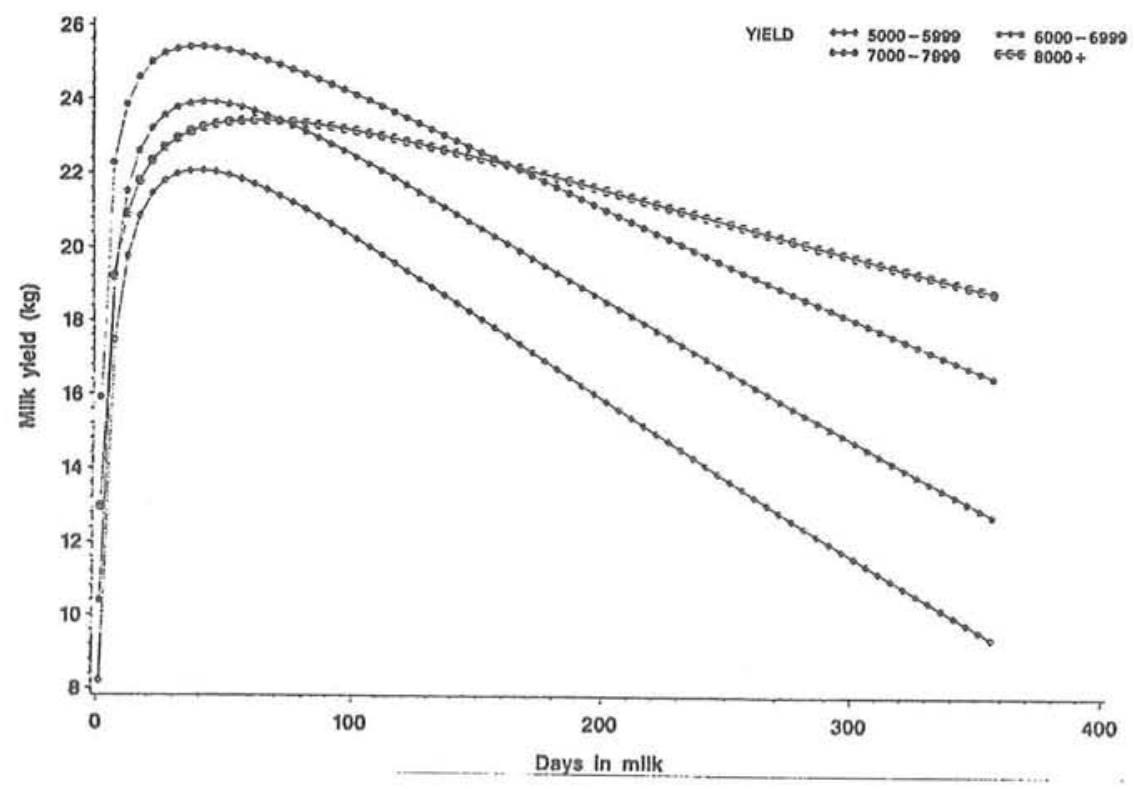

Fig. 1: Lactation curves by total lactation yield class for 1. lactations in herd A (Laktationskurven nach Leistungsklasse für 1. Laktationen in Herde A)

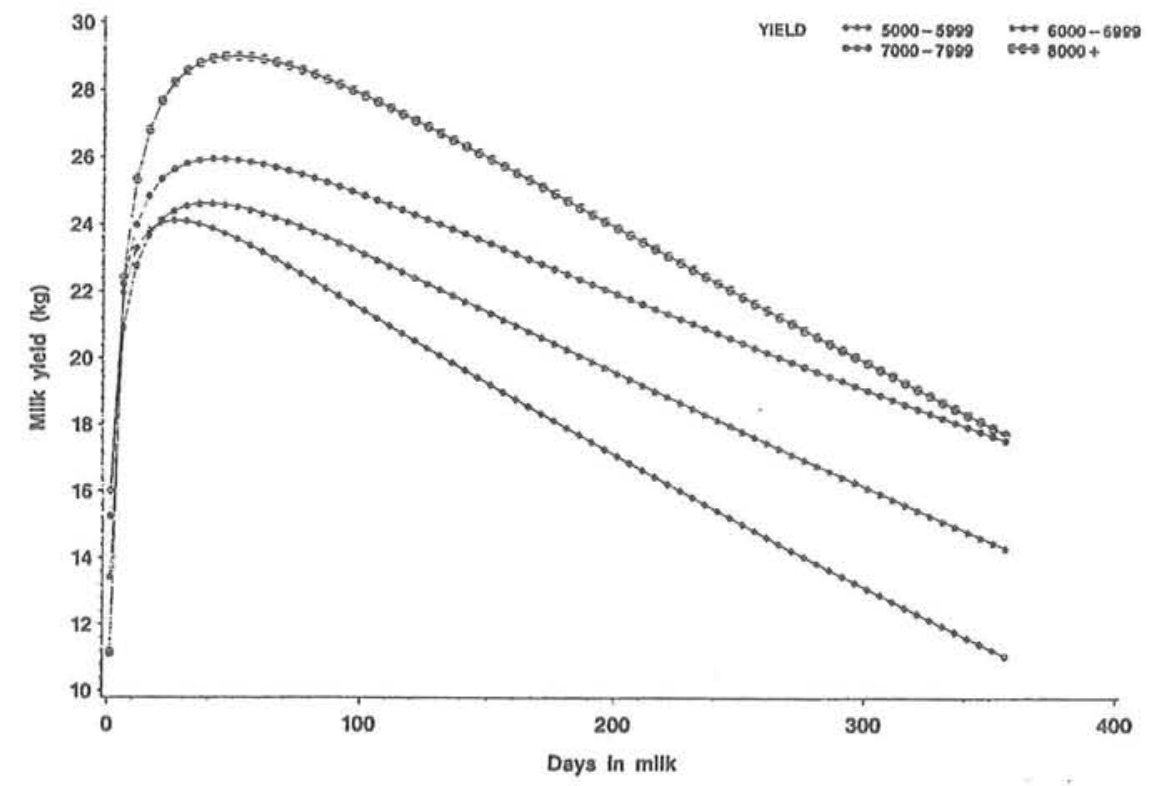

Fig. 2: Lactation curves by total lactation yield class for 1. lactations in herd B (Laktationskurven nach Leistungsklasse für 1. Laktationen in Herde B) 


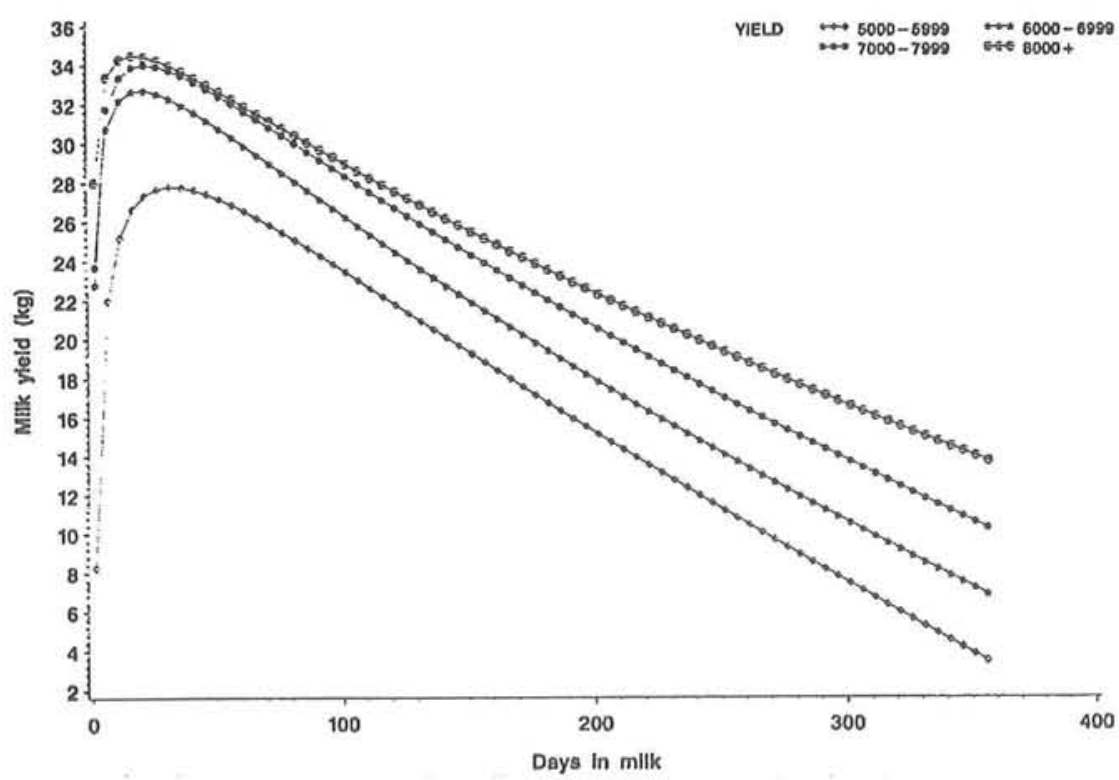

Fig. 3: Lactation curves by total lactation yield class for 3. and higher lactations in herd A (Laktationskurven nach Leistungsklasse für 3. und höhere Laktationen in Herde A)

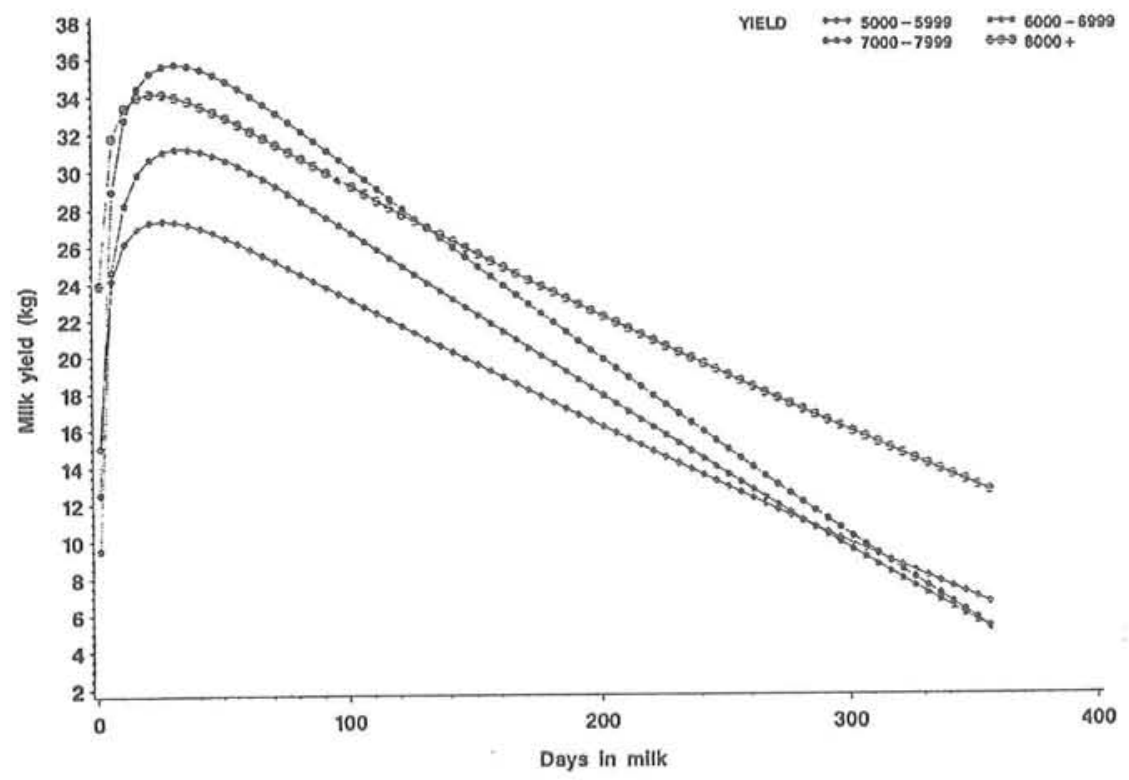

Fig. 4: Lactation curves by total lactation yield class for 3. and higher lactations in herd B (Laktationskurven nach Leistungsklasse für 3. und höhere Laktationen in Herde B) 
an illustration. The observed differences between herds and yield classes may strongly be dependent on environmental factors such as the strategy for re-breeding of cows. It can only be hypothesised that part of the observed differences are also due to genetic factors. However, the results clearly demonstrate that it is very difficult if not impossible to differentiate cows based on records from the very beginning of the lactation. Dairy farmers can only observe their cows on the phenotypic scale and from the results presented here it may be questioned if management practises such as grouping of cows based on early lactation records into yield groups is truly effective.

It is quite clear that preliminary conclusions from this illustration highly depend on the strategy a dairy farmer wishes to apply with respect to the length of lactation. According to DEKKERS et al. (1998) bio-economic model should be used to determine the appropriate length of lactation. The traditional approach of setting the goal for a 305-day lactation with a 365-day calving interval has to be questioned under today's situation with very high producing cows and low prices for calves, especially male calves. For a given herd with cows of high genetic merit capable of producing high yields prolonged calving intervals may be desirable as compared to the traditional approach.

Such a strategy also questions the appropriate definition for persistency. SWALVE and GENGLER (1998) reviewed criteria of persistency. Traditional measurements of persistency such as the production in the last trimester of lactation divided by the one in the first trimester have the disadvantage of being linked to a fixed calving interval in the goal set. The use of random regression models for the genetic evaluation of dairy animals provides an interesting alternative as persistency can be defined in various ways based on the genetic merit expressed as a lactation curve (JAMROZIK et al., 1998). It then may be necessary to provide separate definitions of persistency according to the desired length of lactation. The situation in herd $\mathrm{A}$ as shown here is an example for this since cows that are low starters but maintain profitable yields throughout a long lactation may be more desirable than cows with sharply peaked lactation curves.

The lactation curves presented here may also be of some help to animal nutritionists who wish to predict milk yield in a variety of scenarios for high and low producing cows with different calving intervals. At least in Europe the past ten years have seen a tremendous phenotypic trend in milk yields and hence a continuous update on estimates of parameters for lactation curves appears to be necessary to provide tools for management decisions such as calculation of rations for high yielding cows.

Conclusions from an illustration as presented here should mainly function to identify future topics of research. At present, random regression test day models are proposed for genetic evaluations. Analyses based on daily recording of milk yield could aid in answering a number of unanswered questions, e.g. the impact of few observations per lactation, the appropriate definition of measurements of persistency, the use of many observations per lactation and the possible identification of 'informative' parts of the 
lactation curve, etc.

The project that provided the data for this illustration is ongoing. The data will be used to address the above questions. Once more complete lactations will be available, complete analyses with respect to environmental and genetic effects will be feasible.

\section{Acknowledgement}

The authors wish to thank Prof. Dr. E. Kalm, University of Kiel, for supplying data from the experimental herd 'Karkendamm'. Gratitude is also expressed to the two other participating farms and to the Rinderzuchtverband Mecklenburg-Vorpommern (RMV) for their support.

\section{References}

DEKKERS, J.C.M.; TEN HAAG, J.H.; WEERSINK, A.:

Economic aspects of persistency of lactation in dairy cattle. Livest. Prod. Sci. 53 (1998), 237-252

GUO, Z.; SWALVE, H.H.:

Modelling of the lactation curve as a sub-model in the evaluation of test day records. Proc. Interbull Mtg. Prague, International Bull Evaluation Service, Uppsala, Sweden. Interbull Bull. (1995), No. 11

GUO, Z.; SWALVE, H.H.:

Comparison of different lactation curve sub-models in test day models. Interbull Mtg. Vienna, International Bull Evaluation Service, Uppsala, Sweden. Interbull Bull. No. 16 (1997), 75-79

GUO, Z.:

Modelle zur Beschreibung der Laktationskurve des Milchrindes und ihre Verwendung in Modellen zur Zuchtwertschätzung (Models for the description of lactation curves in dairy cattle and their use in models for genetic evaluation). (1998), Doctor's thesis, University of Göttingen, Germany

HENDERSON, C.R.:

Applications of linear models in animal breeding. (1984), University of Guelph, Guelph, Ontario, Canada

HENDERSON, C.R. JR.:

Analysis of covariance in the mixed model: higher level, nonhomogeneous, and random regressions. Biometrics 38 (1982), 623-640

JAMROZIK, J.; SCHAEFFER, L.R.; LIU, Z.; JANSEN, G.:

Multiple trait random regression test day model for production traits. Interbull Mtg. Vienna, International Bull Evaluation Service, Uppsala, Sweden. Interbull Bull. No. 16 (1997), 43-47

JAMROZIK, J.; JANSEN, G.; SCHAEFFER, L.R.; LIU, Z.:

Analysis of persistency of lactation calculated from a random regression test day model. Proc. Interbull Mtg. Rotorua, International Bull Evaluation Service, Uppsala, Sweden, Interbull Bull. No. 17 (1998), 64-69

MASSELIN, S.; SAUVANT, D.; CHAPOUTOT, P; MILAN, D.

Les modèles d'ajustement des courbes de lactation. Ann. Zootech. 36 (1987), 171-206

MEYER, K.; HILL, W.G.:

Estimation of genetic and phenotypic covariance functions for longitudinal or 'repeated' records by restricted maximum likelihood. Livest. Prod. Sci. 47 (1997), 185-200

MISZTAL, I.:

Strategies for estimating the parameters needed for different test-day models. J. Dairy Sci. (1999), (Submitted)

POOL, M.H.; MEUWISSEN, T.H.E.:

The effect of incomplete lactation records on covariance function estimates in test day models. (1999), Paper G3.4, 50 $0^{\text {th }}$ Ann. Mtg. EAAP, Zürich, Switzerland, August 22-26

OLORI, V.E.:

Utilisation of daily milk records in genetic evaluation of dairy cattle. (1997), Ph.d. thesis, University of Edinburgh, Edinburgh, Scotland 
SCHAEFFER, L.R.; DEKKERS, J.C.M.:

Random regressions in animal models for test-day production in dairy cattle. Proc. $5^{\text {th }}$ World Congr. Genet. Appl. Livest. Prod., Guelph, Ontario, Kanada, 18 (1999), 443-446

SWALVE, H.H.:

Test day models in the analysis of dairy production data - a review. Arch. Tierz., Dummerstorf 38 (1995), 591-612

SWALVE, H.H.:

Use of test day records in genetic evaluation. Proc. 6th World Congr. Genet. Appl. Livest. Prod., SWALVE, H.H.

Armidale, New South Wales, Australia, 23 (1998), 295-302

Theoretical Basis and Computational Methods for Different Test Day Genetic Evaluation Methods. J. Dairy Sci. (1999), (Submitted)

SWALVE, H.H.; GENGLER, N.:

Genetics of lactation persistency. (1998), Proc. Int. Symp. Metabolic Stress in Dairy Cows. British Society of Animal Science (BSAS), EU Concerted Action Group on Genetic Improvement of Functional Traits (GIFT) und British Cattle Veterinary Assoc. (BCVA), Edinburgh, Scotland, October 28-30

VAN DER WERF, J.H.J.; GODDARD, M.E.; MEYER, K.:

The use of covariance functions and random regressions for genetic evaluation of milk production based on test day records. J. Dairy Sci. 81 (1998), 3300-3306

WOOD, P.D.P.:

Algebraic model of the lactation curve in cattle. Nature, London 216 (1967), 164-165

WOOD, P.D.P.:

Algebraic models of the lactation curves for milk, fat and protein production, with estimates of seasonal variation. Anim. Prod. 22 (1976), 35-40

Received: 13.09.1999

Accepted: 11.10 .1999

Authors' addresses

PD Dr. HERMANN H. SWALVE

Forschungsinstitut für die Biologie landwirtschafticher Nutztiere

Wilhelm-Stahl-Allee 2

D-18196 Dummerstorf

Germany

E-Mail: swalve@fon-dummerstorf.de

Dr. ZHIQUN GUO (present address)

Department of Animal Breeding and Genetics

Research Centre Foulum

P.O. Box 50

DK-8830 Tjele

Dänemark

E-Mail: Zhiqun.Guo@agrsci.dk 


\title{
Buchbesprechung
}

\author{
Pferdeklassiker - Pferdebehandlung mit Traditioneller Chinesischer Veterinärmedizin
}

MICHAEL HEERDE

1. Auflage, 214 Seiten, 66 Abbildungen, Sonntag-Verlag Stuttgart, 1999, ISBN-Nr.: 3-87758-147-1, 69,00 DM, $504,00 \mathrm{oS}, 62,50 \mathrm{sFr}$

In Analogie zur Humanmedizin ist auch auf dem Gebiet der Veterinärmedizin ein Trend nach alternativen Behandlungsmethoden zu erkennen. Zweifelsfrei besteht im Zusammenhang mit der Anwendung alternativer Behandlungsmethoden auch ein erheblicher Informationsbedarf. Auf diesen Bedarf einzugehen, ist sicherlich ein Anliegen von Michael Heerde.

Ein weiteres wichtiges Anliegen dieses Buches - einer Übersetzung des 365 Jahre alten „Pferdeklassikers“, einem altchinesischen pferdeheilkundlichen Werk aus der Ming-Dynastie - ist es, die unzulängliche Kommunikation zwischen der europäisierten Veterinärakupunktur und ihren ursprünglichen Wurzeln zu beseitigen.

Traditionelle chinesische Veterinärmedizin (TCVM) beinhaltet sowohl chinesische Kräutermedizin und Diätetik als auch Akkupunktur. Literatur zur TCVM bei Pferden ist äußerst selten und insofern wird mit diesem Buch eine Informationslücke beim Interessenten geschlossen. Der Autor ist bemüht bei der Übersetzung möglichst originalgetreu vorzugehen und trotzdem den Inhalt für den europäischen Leser verständlich und anwendungsorientiert aufzubereiten. Dieses Anliegen wird durch ein Vorwort und einem ersten Kapitel mit Hinweisen zum Verstehen, zur Nutzung und Anwendung dieses Buches unterstützt.

Im Hauptteil des Buches wird neben dem Erörtern der Beurteilung, der Haltung und Fütterung von Pferden sowie einiger propädeutischer Gesichtspunkte auf eine Vielzahl ausgewählter, aber sehr unterschiedlicher Krankheitsbilder eingegangen.

Nach einer kurzen Kasuistik wird in sehr übersichtlicher Form die Behandlung, verbunden mit entsprechenden Rezepturempfehlungen, dargestellt. Oft wird dabei eine kombinierte Therapie mit Kräutern, Waschungen und Nadelungen besprochen. Die Wahl des Akkupunkturpunktes, der Methode mit der man auf diesen einwirkt, ist von der entsprechenden Therapie abhängig. Die Darstellung der entsprechenden Akupunkturpunkte auf beigefügten historischen Tafeln und eine vorangestellte Beschreibung kann nur als Überblick gewertet werden. Interessant ist, daß obwohl Pferde keine Gallenblase besitzen, diesem „Fu-Organ“ besondere Bedeutung beigemessen wird und ihm eigene Leitbahnen und Akupunkturpunkte zugeordnet werden. Abschließend wird bei den einzelnen Krankheitsbildern für die weitere Pflege, Fütterung und Haltung des Pferdes genaue Anweisung gegeben.

Dem interessierten Leser gibt dieses Buch einen guten Einblick in die lange Tradition der fernöstlichen Therapiemethoden, bei denen der Einfluss der gesamten altchinesischen Kultur einschließlich seiner Astrologie, der Geologie und der Landwirtschaft unübersehbar ist. 